\title{
The Pugwash Conferences and the Global COLD WAR \\ Scientists, Transnational Networks, and the Complexity of Nuclear Histories
}

\section{Introduction}

\author{
$\because \quad$ Alison Kraft, Holger Nehring, and Carola Sachse
}

This special issue uses the Pugwash Conferences for Science and World Affairs (henceforth referred to as "Pugwash") as a means to explore important themes in Cold War history. Pugwash is a compelling subject for Cold War studies by virtue of its impact in many countries, the nature of its organization, and the distinctive way it worked, as well as its importance for the relationship between scientists and the Cold War states and its role as a transnational political actor. As Matthew Evangelista has observed, transnational actors were a key feature of the "crowded stage" of Cold War history, yet we know remarkably little about the policies, politics, and impact of these actors in the context of the global Cold War. ${ }^{1}$ As one such actor, Pugwash was part of a growing landscape of what Margaret E. Keck and Kathryn Sikkink have called "transnational advocacy networks," which combined scientific exchange and expertise with the promotion of arms control, disarmament, and non-violent conflict solutions. ${ }^{2}$

Our knowledge of the development, aims, and work of Pugwash in the context of the Cold War remains far from complete. When the first conference was convened in 1957, it afforded a rare channel of communication between scientists from East and West. In subsequent years, it came to provide a forum for second-track nuclear diplomacy. By focusing on Pugwash, we seek to cast new light on the relationship between scientists and Cold War policies and

1. Matthew Evangelista, "Transnational Organizations and the Cold War," in Melvyn P. Leffler and Odd Arne Westad, eds., The Cambridge History of the Cold War, Vol. 3 (Cambridge, UK: Cambridge University Press, 2010), p. 421; and Akira Iriye, Global Community: The Role of International Organizations in the Making of the Contemporary World (Berkeley: University of California Press, 2004).

2. Margaret E. Keck and Kathryn Sikkink, Activists beyond Borders: Advocacy Networks in International Politics (Ithaca, NY: Cornell University Press, 1998).

Vol. 20, No. 1, Winter 2018, pp. 4-30, doi:10.1162/jcws_e_00799

(c) 2018 by the President and Fellows of Harvard College and the Massachusetts Institute of Technology 
politics, on the role of inter- and transnational non-governmental organizations acting "across the blocs" and around the globe during the Cold War, and on the debates about nuclear proliferation and arms control within civil society beyond the confines of governmental actors. ${ }^{3}$ The contributions to this themed issue focus on Pugwash in six national contexts: Austria (Elisabeth Röhrlich), China (Gordon Barrett), Czechoslovakia (Doubravka Olšáková), Japan (Akira Kurosaki), the United Kingdom (Alison Kraft), and West Germany (Carola Sachse). With an emphasis on the period from the organization's founding into the 1970s, these case studies bring together new perspectives on Pugwash that move beyond the Soviet Union and the United States.

Individually and collectively, the articles show how national patterns of engagement with Pugwash related to and were shaped by international and global concerns. The authors explain how the development of Pugwash in these national settings was shaped by experiences of World War II; by each country's position relative to nuclear weapons, the arms race, and Cold War geopolitics; and by conceptions about the role of science and scientists in nation-building and national sovereignty. ${ }^{4}$ Together, the articles bring out the diverse experiences of individual scientists living and working within particular political systems and polities during the Cold War, including the leeway for, limits to, and repercussions of expressing dissenting views on nuclear issues in various national settings. In so doing, they enrich our understanding of what Jessica Wang has called the "uneasy, ambivalent cultural space" scientists occupied during the Cold War. ${ }^{5}$ Collectively, these Pugwash histories do for transnational non-governmental actors and second-track diplomacy what Grégoire Mallard's recent work has done for international organizations such

3. Patrick Major and Rana Mitter, eds., Across the Blocs: Exploring Comparative Cold War Cultural and Social History (London: Routledge, 2004); and Itty Abraham, "The Ambivalence of Nuclear Histories," Osiris, Vol. 21, No. 1 (January 2006), pp. 49-65.

4. See, for example, Jon Agar, Science in the Twentieth Century and Beyond (Cambridge, UK: Polity Press, 2012), esp. pp. 354-366; Itty Abraham, The Making of the Indian Atomic Bomb: Science, Secrecy and the Postcolonial State (London: Zed, 1998); Gabrielle Hecht, The Radiance of France: Nuclear Power and National Identity after World War II (Cambridge, MA: MIT Press, 2009); and Angela N. H. Creager, Life Atomic: A History of Radioisotopes in Science and Medicine (Chicago: University of Chicago Press, 2013).

5. Jessica Wang, "Scientists and the Problem of the Public in Cold War America, 1945-1960," Osiris, Vol. 17 (January 2002), p. 325; Jessica Wang, American Science in an Age of Anxiety: Scientists, Anticommunism, and the Cold War (Chapel Hill: University of North Carolina Press, 1999); and Richard Beyler, Alexei B. Kojevnikov, and Jessica Wang, "Purges in Comparative Perspective: Rules for Exclusion and Inclusion in the Scientific Community Under Pressure," Osiris, Vol. 20 (2005), pp. 2348. 
as the European Atomic Energy Community and the International Atomic Energy Agency (IAEA): Pugwash highlights another strand of nuclear negotiations, a field distinctive for the involvement of scientists, which adds texture and depth to this area of Cold War studies. ${ }^{6}$

According to Jan Voorhees, the impact of transnational organizations on government policy can be gauged "by examining either the direct influence by such communities on state policy or their indirect influence, that is, their ability to influence the climate of opinion in which policy is made." Pugwash arguably achieved the latter, and it may have also achieved the former. That it was seen as a valuable and credible actor in the Cold War landscape is indicated by the messages of support and encouragement from heads of state that, in the 1960s, became a part of the opening ceremony of the annual conferences. The relevance of Pugwash, and evidence that its contributions mattered politically, is also suggested in acknowledgments of its work by senior political figures from East and West, including Henry Kissinger and Mikhail Gorbachev, as well as by the joint awarding in 1995 of the Nobel Peace Prize to Pugwash and its long-serving secretary general, Joseph (originally Józef) Rotblat, "for their efforts to diminish the part played by nuclear arms in international politics and, in the longer run, to eliminate such arms." ${ }^{\text {" }}$

This introduction sets out the historical and historiographical contexts of our project and provides an analytical and conceptual framework in which to situate the individual articles. It begins with a discussion of the historiography before outlining key moments in and aspects of the historical development of Pugwash. It then considers why and how the history of this scientist-led initiative, which in 1991 registered with the United Nations (UN) as an international non-governmental organization (INGO), matters in the context of Cold War studies. ${ }^{9}$

6. Grégoire Mallard, Fallout: Nuclear Diplomacy in an Age of Global Fracture (Chicago: Chicago University Press, 2014). On the history of the IAEA, see the research project directed by Elisabeth Röhrlich (Vienna), available online at http://iaea-history.univie.ac.at/.

7. James Voorhees, Dialogue Sustained: The Multilevel Peace Process and the Dartmouth Conference (Washington, DC: U.S. Institute of Peace Press, 2002), p. 25, cited in Evangelista, "Transnational Organizations," p. 418.

8. See "The Nobel Peace Prize 1995," Nobelprize.org, online at http://www.nobelprize.org/nobel _prizes/peace/laureates/1995/.

9. For a numerical account of the strength of INGOs in different fields and over time, see Kjell Skjelsbaek, "The Growth of International Nongovernmental Organization in the Twentieth Century," International Organization, Vol. 25, No. 3 (Summer 1971), esp. p. 429; and Akira Iriye, "A Century of NGOs," Diplomatic History, Vol. 23, No. 3 (Summer 1999), pp. 421-435. 


\section{Historiography}

The seminal work on Pugwash is Matthew Evangelista's 1997 book, Unarmed Forces, which offers a nuanced study of the role of Pugwash as well as the International Physicians for the Prevention of Nuclear War (IPPNW) in the Soviet Union. It remains the only in-depth study of the movement that situates the Soviet Pugwash group within the context of international politics. ${ }^{10}$ In particular, Evangelista highlights the role of Pugwash in the preparation of the Antiballistic Missile (ABM) Treaty in 1972 and the Intermediate-Range Nuclear Forces (INF) Treaty in 1987. He deftly combines the assessment of transfers of ideas across the Iron Curtain with a political sociology of power in the Soviet Union - an approach indicative perhaps of the need for and the advantages of taking an interdisciplinary approach to Pugwash. ${ }^{11}$ Evangelista's work reveals much about when and how transnationally organized scientific expertise could be mobilized and deployed in a particular place and time, and with particular purpose, during the Cold War. It underlines, too, the importance of Pugwash for a fuller understanding of the Cold War. This themed issue of the journal takes its cue from Unarmed Forces. We see this special issue as a means to begin to address the dearth of work on Pugwash and hope that it might also provides a starting point for a new engagement with Pugwash by historians from many fields.

Attention to Pugwash has remained fragmentary and diffuse, making an assessment of the historiography a challenge. Pugwash sits awkwardly within the Cold War studies literature, as it occupies a space between histories of science, diplomacy, international relations, and peace studies. Although Pugwash has been touched on briefly in work on anti-nuclear protest and disarmament,

10. Matthew Evangelista, Unarmed Forces: The Transnational Movement to End the Cold War (Ithaca, NY: Cornell University Press, 1999), p. 21; and Robert English, "The Sociology of New Thinking: Elites, Identity Change, and the End of the Cold War," Journal of Cold War Studies, Vol. 7, No. 2 (Spring 2005), pp. 43-80. See also the detailed overview by Mark Kramer, "Special Issue: The Collapse of the Soviet Union (Part 1): Introduction," Journal of Cold War Studies, Vol. 5, No. 1 (Winter 2003), pp. 3-16; and Mark Kramer, "Special Issue: The Collapse of the Soviet Union (Part 2): Introduction," Journal of Cold War Studies, Vol. 5, No. 4 (Fall 2003), pp. 3-42. On the general context of arms control negotiations see Susanna Schrafstetter and Stephen Twigge, Avoiding Armageddon: The United States, Western Europe and the Struggle for Nuclear Non-Proliferation, 1945-1970 (New York: Praeger, 2004).

11. On the Soviet nuclear weapons program, see David Holloway, Stalin and the Bomb: The Soviet Union and Atomic Energy, 1939-1956 (New Haven: Yale University Press, 1994); David Holloway, "Physics, the State, and Civil Society in the Soviet Union," Historical Studies in the Physical and Biological Sciences, Vol. 30, No. 1 (January 1999), pp. 173-192; and Michael D. Gordin, Red Cloud at Dawn: Truman, Stalin, and the End of the Atomic Monopoly (New York: Farrar, Straus \& Giroux, 2009). See also the extraordinary collection of declassified documents: L.D. Ryabev et al., eds., Atomnyi proekt SSSR: Dokumenty i materialy, 1939-1956, 9 vols. (Moscow: Nauka, Fizmatlit, 1999-2007). 
it has tended to fall in the interstices between various historiographical traditions. In part, this reflects methodological difficulties in tackling Pugwash. Because nuclear weapons were the principal concern within Pugwash throughout the Cold War, its histories are beset with the problem of gaining access to relevant primary sources, many of which remain classified. Moreover, the nature of its work, as an informal channel of East-West communication and a site of second-track diplomacy, render its influence and achievements difficult to assess. In addition, its organizational structure makes for difficulties, as scholars need to engage both with the national Pugwash groups and with Pugwash as a single movement, as well as with the work of the Pugwash Continuing Committee, which articulated between and coordinated the national and supranational activities of the movement. The relationships among the different national groups and between them and the Continuing Committee are central to understanding Pugwash as a site of transnational exchange and its role as a politically attuned transnational actor. Its presence in many countries demands that Pugwash be situated within scholarship specific to a particular national context, and the nation-state approach offers one basis for investigating its transnational character.

Evangelista's work aside, there is a dearth of scholarship on Pugwash. Several accounts have been produced by or about those involved in or close to Pugwash. ${ }^{12}$ Pugwash also features within the broader literature on nuclear history, in particular Lawrence Wittner's magisterial trilogy on anti-nuclear protest. ${ }^{13}$ There are also biographies of scientists involved in Pugwash, notably

12. Leonard E. Schwartz, "Perspective on Pugwash," International Affairs, Vol. 43, No. 3 (July 1967), pp. 498-515. Also, see Bernd W. Kubbig, "Communicators in the Cold War: The Pugwash Conferences, the US-Soviet Study Group and the ABM Treaty," PRIF Reports, No. 44 (1996), pp. 1-3; Bernd W. Kubbig, Wissen als Machtfaktor im Kalten Krieg: Naturwissenschaftler und die Raketenabwehr der USA (Frankfurt: Campus, 2004); Corinna Hauswedell, Friedenswissenschaften im Kalten Krieg: Friedensforschung und friedenswissenschaftliche Initiativen in der Bundesrepublik Deutschland in den achtziger Jahren (Baden-Baden: Nomos, 1997); Joseph Rotblat, Pugwash: The First Ten Years: History of the Conferences of Science and World Affairs (New York: Humanities Press, 1967); Joseph Rotblat, Scientists and the Quest for Peace: A History of the Pugwash Conferences (Cambridge, MA: MIT Press, 1972); E. Rabinowitch, "Pugwash-History and Outlook," Bulletin of the Atomic Scientists, Vol. 8, No. 7 (September 1957), pp. 243-248; and Sandra Iono Butcher, "The Origins of the Russell-Einstein Manifesto," Pugwash History Series, No. 1 (May 2005), available online at https://pugwashconferences.files.wordpress.com/2014/02/2005_history_origins_of_manifesto3.pdf. On the historiographical assessment of such interpretations, see Benjamin Ziemann, "Perspektiven der Historischen Friedensforschung," in Benjamin Ziemann, ed., Perspektiven der Historischen Friedensforschung (Essen: Klartext, 2002), pp. 16-19.

13. Lawrence S. Wittner, The Struggle against the Bomb, Vol. 1: One World or None: A History of the World Nuclear Disarmament Movement through 1953 (Stanford, CA: Stanford University Press, 1993); Lawrence S. Wittner, The Struggle against the Bomb, Vol. 2: Resisting the Bomb: A History of the World Nuclear Disarmament Movement, 1954-1970 (Stanford, CA: Stanford University Press, 1997); Lawrence S. Wittner, The Struggle against the Bomb, Vol. 3, Toward Nuclear Abolition: A History of the 
the biography of Rotblat by Andrew Brown. Pugwash also features occasionally in work on senior scientists whose engagement with it was peripheral or sporadic. ${ }^{14}$ More critical analyses of Pugwash have presented scientists campaigning for arms control as unwitting assets of Soviet foreign policy—or worse, as direct threats to Western liberal democracies. ${ }^{15}$ The attempts from the beginning of the Cold War by the Soviet Union and other countries from the Eastern bloc to influence debates about peace, conflict resolution, and arms control are well documented, but the overall relevance of these interventions and their impact on policy formulation remains far from clear. ${ }^{16}$

The lack of attention paid by Cold War historians to organizations such as Pugwash is, in part, a reflection of the belated engagement among historians of the Cold War with transnational actors, where existing work has focused primarily on the politics of protest and the role of culture. ${ }^{17}$ Science and technology studies still have to find their place as an established part of Cold

World Nuclear Disarmament Movement, 1971 to the Present (Stanford, CA: Stanford University Press, 2003); and Lawrence S. Wittner, "About the Peace Movements and Their Relations: A Comparison of Their Development and Impact in East and West," Archiv für Sozialgeschichte, Vol. 45 (2005), pp. 373-406.

14. Andrew Brown, Keeper of the Nuclear Conscience: The Life and Work of Joseph Rotblat (Oxford, UK: Oxford University Press, 2012); and Richard Maguire, "Scientists Dissent amid the United Kingdom Government's Nuclear Weapons Programme,” History Workshop Journal, No. 63 (Spring 2007), pp. 113-135. On Blackett, see Mary-Jo Nye, "A Physicist in the Corridors of Power: P. M. S. Blackett's Opposition to Atomic Weapons Following the War," Physics in Perspective, Vol. 1 No. 2 (June 1999), pp. $136-146$.

15. Jeffrey Herf, War by Other Means: Soviet Power, West German Resistance, and the Battle of the Euromissiles (New York: The Free Press, 1991); Jeffery Herf, "War, Peace, and the Intellectuals: The West German Peace Movement,” International Security, Vol. 10, No. 4 (April 1986), pp. 172-200; and Gert Krell et al., "The West German Peace Movement," International Security, Vol. 11, No. 2 (October 1986), pp. 193-215.

16. See, for example, Philip Deery, "The Dove Flies East: Whitehall, Warsaw and the 1950 World Peace Congress," Australian Journal of Politics and History, Vol. 48, No. 4 (December 2002), pp. 449468; Wes Ullrich, "Preventing 'Peace': The British Government and the Second World Peace Congress," Cold War History, Vol. 11, No. 3 (August 2011), pp. 341-362; and Gerhard Wettig, "The Last Soviet Offensive in the Cold War: Emergence and Development of the Campaign against NATO Euromissiles, 1979-1983," Cold War History, Vol. 9, No. 1 (February 2009), pp. 79-110. More recent research on the social history of Communism in West Germany in particular is rather skeptical about the impact of attempts at infiltration. See Till Kössler, Abschied von der Revolution: Kommunisten und Gesellschaft in Westdeutschland 1945-1968 (Düsseldorf: Droste, 2004).

17. See, for example, Jeremi Suri, Power and Protest: Global Revolution and the Rise of Détente (Cambridge, MA: Harvard University Press, 2005); Martin Klimke, The Other Alliance: Student Protest in West Germany and the United States in the Global Sixties (Princeton, NJ: Princeton University Press, 2009); Holger Nehring, Politics of Security: British and West German Protest Movements and the Early Cold War, 1945-1970 (Oxford, UK: Oxford University Press, 2013); Major and Mitter, eds., Across the Blocs; K. J. Holsti, "Scholarship in an Area of Anxiety: The Study of International Politics during the Cold War," Review of International Studies, Vol. 24, No. 5 (December 1998), pp. 17-46; and Iris Schröder, "Die Wiederkehr des Internationalen: Eine einführende Skizze," Zeithistorische Forschungen / Studies in Contemporary History, Vol. 8, No. 3 (March 2011), pp. 111-121. 
War studies. ${ }^{18}$ Underlying this neglect has been the assumption of a straightforward "militarization" of Cold War science and society that has persisted in defining the field, although more recent research has highlighted the ambiguities of Cold War science. ${ }^{19}$ The predominant impression is still that expressed by Michael Dennis in 1994: "Looking at the civilian in postwar America is much like looking at a map of an archipelago composed of discrete islands of civilian life connected to a larger, largely invisible military framework." ${ }^{20}$ Although research on the "wizards of Armageddon," the defense intellectuals, engineers, and scientists who advised the U.S., British, and Soviet governments on matters relating to nuclear strategy and technology, and armaments more generally, is now well established, we know much less about the scientists who disagreed with the policies of their governments. ${ }^{21}$

Similarly, historians of science have been hesitant to adopt transnational approaches and tackle transnational actors, including Pugwash. ${ }^{22}$ Simone

18. See Claudia Kemper, Medizin gegen den Kalten Krieg: Ärzte in der anti-atomaren Friedensbewegung der 1980er Jahre (Göttingen: Wallstein, 2016); and Christoph Laucht "Transnational Professional Activism and the Prevention of Nuclear War in Britain," Journal of Social History (forthcoming 2018).

19. Joy Rohde, Armed with Expertise: The Militarization of American Social Research during the Cold War (Ithaca, NY: Cornell University Press, 2013). For a different though nonetheless pertinent field, see Joel Isaac, "The Human Sciences in Cold War America," Historical Journal, Vol. 50, No. 3 (September 2007), pp. 725-746; and Jamie Cohen-Cole, The Open Mind: Cold War Politics and the Science of Human Nature (Chicago: University of Chicago Press, 2014).

20. Michael Aaron Dennis, “'Our First Line of Defense': Two University Laboratories in the Postwar American State," Isis, Vol. 85, No. 3 (September 1994), p. 451. We owe this reference to John Krige, American Hegemony and the Postwar Reconstruction of Science in Europe (Cambridge, MA: MIT Press, 2006), p. 11.

21. A point made powerfully by Krige, American Hegemony, esp. ch. 2. See the overview by Christoph Bluth, "Science and Technology," in Saki R. Dockrill and Geraint Hughes, eds., Palgrave Advances in Cold War History (Basingstoke, UK: Palgrave 2006), pp. 189-209. As examples for literature on the influence of defense intellectuals, see Fred Kaplan, The Wizards of Armageddon (Stanford, CA: Stanford University Press, 1983); Campbell Craig, Destroying the Village: Eisenhower and Thermonuclear War (New York: Columbia University Press, 1998); Bruce Kucklick, Blind Oracles: Intellectuals and War from Kennan to Kissinger (Princeton, NJ: Princeton University Press, 2007); Ron Robin, The Making of the Cold War Enemy: Culture and Politics in the Military-Intellectual Complex (Princeton, NJ: Princeton University Press, 2003); Peter Goodchild, Edward Teller: The Real Dr. Strangelove (Cambridge, MA: Harvard University Press, 2004); Sharon Ghamari-Tabrizi, The World of Hermann Kahn: The Intuitive Science of Thermonuclear War (Cambridge, MA: Harvard University Press, 2005); and Antoine Bousquet, The Scientific Way of Warfare: Order and Chaos on the Battlefields of Modernity (Oxford, UK: Oxford University Press, 2009), ch. 3. See also Bernd Greiner, Tim B. Müller, and Claudia Weber, eds., Macht und Geist im Kalten Krieg (Hamburg: Hamburger Edition, 2011), especially the essays by Paul Erickson, Ron Robin, Philip Rocco, Slawa Gerowitsch, and Michael D. Gordin.

22. In 1995, Thomas Risse-Kappen defined "transnational" as the "regular interactions across national boundaries when at least one actor is a non-state agent or does not operate on behalf of a national government or an intergovernmental organization." See Thomas Risse-Kappen, "Bringing Transnational Relations Back In: Introduction," in Risse-Kappen, ed., Bringing Transnational Relations Back In: Non-state Actors, Domestic Structures and International Institutions (Cambridge, UK: Cambridge University Press, 1995), p. 3. For a general discussion on the contested meaning of "transnational," see 
Turchetti, Nestor Herran, and Soraya Boudia have recently drawn attention to this problem in their introduction to a special issue of the British Journal of the History of Science on transnational history. They call for a new engagement with this approach on the part of historians of science. ${ }^{23}$ Moreover, despite a recent emphasis on "de-centering the Cold War," Anglophone scholarship continues to have little awareness of scientists who operated in contexts in which nuclear armament was not a realistic option, as in West Germany, Japan, and Austria. Itty Abraham's and Jahnavi Phalkey's recent studies on India illustrate the rich historical insights that can arise from work at the intersection between Cold War studies and the history of science. ${ }^{24}$

Rotblat's observation in 1958 that the fact "that the meetings take place [is] as important as the subjects of the meetings" highlights the way the fundamental contribution of Pugwash lay in creating the possibility for, and conditions conducive to, dialogue across political and ideological divides. ${ }^{25}$ But precisely how this was achieved and its impact across time and place remain open to debate. As the studies by Evangelista, Thomas Risse-Kappen, Bernd W. Kubbig, and Kai-Henrik Barth have shown, assessing and gauging the influence of scientists working individually or collectively within nuclear arms negotiations and policy is far from straightforward. ${ }^{26}$ We would emphasize, too, the role of Pugwash in knowledge creation in the course of

Patricia Clavin, "Defining Transnationalism," Contemporary European History, Vol. 14, No. 4 (November 2005), pp. 421-439. See the pioneering early work by Joseph S. Nye, Jr., and Robert O. Keohane, "Transnational Relations and World Politics: An Introduction," International Organization, Vol. 25, No. 3 (Summer 1971), pp. 329-349.

23. Simone Turchetti, Nestor Herran, and Soraya Boudia, "Introduction: Have We Ever Been Transnational? Towards a History of Science across and beyond Borders," British Journal for the History of Science, Vol. 45, No. 3 (September 2012), pp. 319-336.

24. Jahnavi Phalkey, Atomic India: Big Science in Twentieth Century India (Ranikhet, India: Permanent Black, 2013); and Abraham, Making. See also Jadwiga E. Pieper Mooney and Fabia Lanza, eds., De-Centering Cold War History: Local and Global Change (London: Routledge, 2013); Stephan Geier, Schwellenmacht: Bonns heimliche Atomdiplomatie von Adenauer bis Schmidt (Paderborn: Schöningh, 2013); Michael Knoll, Atomare Optionen: Westdeutsche Kernwaffenpolitik in der Ära Adenauer (Frankfurt am Main: Peter Lang, 2013); Susanna Schrafstetter, Die dritte Atommacht: Britische Nichtverbreitungspolitik im Dienst von Statussicherung und Deutschlandpolitik 1952-1968 (Munich: Oldenbourg, 1999); Marc Cioc, Pax Atomica: The Nuclear Defense Debate in West Germany during the Adenauer Era (New York: Columbia University Press, 1988); and Hans-Peter Schwarz, "Adenauer und die Kernwaffen," Vierteljahrshefte für Zeitgeschichte, Vol. 37, No. 4 (October 1989), pp. 567-593.

25. Joseph Rotblat, September 1958, in Papers of Sir Joseph Rotblat (RTBT), Churchill Archives Center (CAC), University of Cambridge, UK, 5/3/1/3.

26. Evangelista, Unarmed Forces; Kubbig, Wissen; Thomas Risse-Kappen, "Ideas Do Not Float Freely: Transnational Coalitions, Domestic Structures, and the End of the Cold War," International Organization, Vol. 48, No. 2 (Spring 1994), pp. 185-214; Thomas Risse-Kappen, "Did 'Peace through Strength' End the Cold War?: Lessons from INF,” International Security, Vol. 16, No. 1 (Summer 1991), pp. 162-188; and Kai-Henrik Barth, "Catalysts of Change: Scientists as Transnational Arms Control Advocates in the 1980s," Osiris, Vol. 21, No. 1 (January 2006), pp. 182-206. 
technical/scientific conversations around the Pugwash table regarding various aspects of nuclear weapons. For example, awareness of the dangers that radiation potentially posed to human health was an important factor for establishing what Nina Tannenwald calls the "nuclear taboo" surrounding the use of nuclear weapons. Pugwash was a key early forum in which these dangers were discussed by scientists. The sharing and circulation of ideas and data on this topic contributed to new understanding of the dangers of fallout. ${ }^{27}$ Indeed, these dangers - specifically, the problem of radioactive fallout from hydrogen bomb tests-underpinned a new wave of concern about nuclear weapons and the arms race in the mid-1950s that provides crucial context for the origins of Pugwash.

\section{Pugwash: Formation and Early Development}

How and why did Pugwash first emerge and gain standing as a valued actor in Cold War international affairs? In March 1954 the U.S. thermonuclear test Castle Bravo went badly wrong. The explosion was much larger than expected and showered the crew of a Japanese fishing boat, the Daigo Fukuryū Maru (Lucky Dragon 5), located in supposedly safe waters outside the test-site exclusion zone, with radioactive fallout that caused radiation sickness among the crew and the death of one crewman. ${ }^{28}$ Prior to this, the thermonuclear "turn" in the arms race had taken place quickly and in secret. ${ }^{29}$ The Fukuryu Maru I Castle Bravo accident not only became a diplomatic flashpoint between Japan and the United States but also directed global attention to nuclear weapons. ${ }^{30}$ Widely covered by the international press, the event punctured the secrecy surrounding nuclear weapons and focused worldwide attention on the dangers of

27. Nina Tannenwald, The Nuclear Taboo: The United States and the Non-Use of Nuclear Weapons since 1945 (Cambridge, UK: Cambridge University Press, 2007).

28. Many Marshallese Islanders and a smaller number of U.S. military personnel were also contaminated. See M. Susan Lindee, Suffering Made Real: American Science and the Survivors at Hiroshima and Nagasaki (Chicago: Chicago University Press, 1994).

29. Michael Aaron Dennis, "Secrecy and Science Revisited: From Politics to Historical Practice and Back," in Judith Reppy, ed., "Secrecy and Knowledge Production," Occasional Paper No. 23, Peace Studies Program, Cornell University, October 1999, esp. p. 2; Peter Galison, "Removing Knowledge: The Logic of Modern Censorship," in Robert Proctor and Londa Schiebinger, eds., Agnotology: The Making and Unmaking of Ignorance (Stanford, CA: Stanford University Press, 2008), pp. 37-54; and Peter J. Westwick, "Secret Science: A Classified Community in the National Laboratories," Minerva, Vol. 38, No. 4 (December 2000), pp. 363-391.

30. See Matthew Jones, After Hiroshima: The United States, Race and Nuclear Weapons in Asia, 19451965 (Cambridge, UK: Cambridge University Press, 2010), pp. 162-198. 
the hydrogen bomb and the arms race generally. In particular, it drew attention to a new problem: radioactive fallout-new kinds of intensely radioactive isotopes formed during thermonuclear explosions. As one commentator observed, Bravo "made the world fallout-conscious." 31 The dramatic consequences of this nuclear accident transformed perceptions of the arms race, reconfiguring the contours of nuclear politics by igniting concerns around the world about the dangers posed by the hydrogen bomb. Scientists played a key role in this transformation, not least in challenging official claims that fallout posed little danger to health and in bringing the fallout problem before the public.

At the time, little was known about fallout, although the possibility that it might pose dangers to human health was already recognized. Still, its dangers were unclear and contested, the subject of intense debate among scientists. The fallout issue lent momentum to debates about the hydrogen bomb and nuclear tests and was a key factor in spurring opposition to nuclear weapons in the mid-1950s on the part of politicians and, increasingly, the public. For some scientists, the hydrogen bomb opened a new chapter in the tradition of scientific social responsibility.

The idea that the special competence of scientists bestowed on them a special responsibility within and to wider society was not new. In the wake of Hiroshima and Nagasaki this idea had underpinned the "scientists" movement." ${ }^{32}$ National organizations such as the Federation of Atomic Scientists (FAS) in the United States (quickly renamed the Federation of American Scientists) and the British Atomic Scientists Association (ASA) founded by Rotblat had called on politicians to establish the means for international control over nuclear weapons in order to prevent an arms race. The World Federation of Scientific Workers (WFSW), a Communist-led organization founded in

31. Attributed to Daniel Lang, science writer at the New Yorker magazine by Catherine Caufield, Multiple Exposures: Chronicles of the Radiation Age (New York: Perennial Library, 1989), p. 115.

32. Fritz Bartel, "Surviving the Years of Grace: The Atomic Bomb and the Specter of World Government, 1945-1950," Diplomatic History, Vol. 39, No. 2 (April 2015), pp. 275-302; Daniel J. Kevles, The Physicists: The History of a Scientific Community in Modern America (Cambridge, MA: Harvard University Press, 1995); Martin Kuznick, "The Birth of Scientific Activism," Bulletin of the Atomic Scientists, Vol. 44, No. 10 (December 1988), pp. 39-43; Christoph Laucht, Elemental Germans: Klaus Fuchs, Rudolf Peierls and the Making of British Nuclear Culture, 1939-59 (Basingstoke, UK: Palgrave, 2012); Kelly Moore, Disrupting Science: Social Movements, American Scientists and the Politics of the Military, 1945-1975 (Princeton, NJ: Princeton University Press, 2008); Sylvan S. Schweber, In the Shadow of the Bomb: Oppenheimer, Bethe, and the Moral Responsibility of the Scientist (Princeton, NJ: Princeton University Press, 2007); Alice Kimball Smith, A Peril and a Hope: The Scientists' Movement in America, 1945-47 (Chicago: University of Chicago Press, 1965); and Donald A. Strickland, Scientists in Politics: The Atomic Scientists' Movement, 1945-1946 (Lafayette, IN: Purdue University Studies, 1968). 
1946 and rooted in interwar Franco-British scientific networks, was likewise vehemently opposed to U.S. (but not Soviet) nuclear weapons and worked to build and maintain links across the East-West divide. ${ }^{33} \mathrm{~A}$ decade later, in response to the thermonuclear age, concerned scientists sought new ways to express their views and novel means for challenging the political orthodoxies of the Cold War.

Crucial to the establishment of Pugwash was the Russell-Einstein Manifesto of July 1955, one manifestation of the resurgent opposition to nuclear weapons, especially the hydrogen bomb, among concerned scientists. The chief architect of the manifesto was the British mathematician, philosopher, and Nobel laureate Bertrand Russell, although it was formulated in close cooperation with the French physicist and acting WFSW President Frédéric Joliot-Curie. All but one of the eleven signatories to the manifesto were Nobel laureates, including most prominently Albert Einstein. Together the scientists represented five countries (Percy W. Bridgman, Hermann J. Muller, and Linus C. Pauling from the United States; Max Born, Cecil F. Powell, and Rotblat from Great Britain; Hideki Yukawa from Japan; and Polish physicist Leopold Infeld from Poland, the sole representative from behind the Iron Curtain). ${ }^{34}$ The manifesto sought to mobilize scientists around the world to take a stand against nuclear weapons and to alert the general public to the recent change in the arms race. In stark, carefully crafted terms, it warned of the new dangers that placed the future of the human race "in doubt" and emphasized the need for dialogue between East and West based on a "new way of thinking," something long advocated by Einstein. The manifesto closed by urging scientists to "remember your humanity and forget the rest." Widely covered in the press around the world, the manifesto "touched a chord with the public," as Rotblat, the most junior signatory, later recalled. ${ }^{35}$

The manifesto urged scientists to meet "in conference" to discuss and confront the dilemmas posed by nuclear weapons-a rallying call that would prove important for the origins of Pugwash. Transforming this idea into a viable organizational form was fraught with political, logistical, and practical difficulties. Moreover, acutely aware of the pitfalls of any hint of leftism, Russell insisted that the conference of scientists had to be seen to be politically neutral and independent and, to this end, ought not to be associated with

33. Patrick Petitjean, "The Joint Establishment of the World Federation of Scientific Workers and of UNESCO after World War II,” Minerva, Vol 46, No. 2 (June 2008), pp. 247-270.

34. "The Russell-Einstein Manifesto," Pugwash Conferences on Science and World Affairs, available online at http://pugwash.org/1955=07/09/statement-manifesto/.

35. Rotblat, Pugwash, p. 12. 
other organizations, including the WFSW. Beginning in late 1955, Russell and Joliot-Curie, working closely with E. H. Burhop, Powell, and Rotblat in London, set about organizing a conference. ${ }^{36}$ This came to fruition in July 1957 when 22 scientists from ten countries met in the Canadian fishing village of Pugwash, Nova Scotia, on the estate of the Canadian-American steel magnate Cyrus Eaton to "assess the perils to humanity which have arisen as a result of the development of weapons of mass destruction." ${ }^{37}$ This was the inaugural meeting of what would become known as the Pugwash Conferences on Science and World Affairs. ${ }^{38}$ From the outset, the meetings were informal, with scientists invited as individuals rather than as representatives of their government or as "members of this or that group." They referred to themselves as "Pugwashites." 39 Pugwash constituted a distinctive form of intellectual activism on the part of an elite group of scientists concerned to challenge fundamentally the logic of the arms race. It sought to bring scientists from across the East-West divide together to tackle the problems posed by nuclear weapons and to develop the "new way of thinking" called for in the manifesto. Its three core objectives, set out at the first meeting, were to influence governments, to act as a channel of communication among scientists, and to educate the public.

Formed, in effect, to advance the values, principles, and aims of the Russell-Einstein Manifesto, Pugwash was premised on the idea that scientists shared a set of values that transcended both national boundaries and political ideologies. Accordingly, it regarded itself as a "modest, conscientious and hopeful" initiative that sought to develop into "a force for peace." ${ }^{40}$ A fivemember Continuing Committee was set up at the end of the 1957 meeting in Nova Scotia. Its purpose was to act as Pugwash's permanent representation and to organize further conferences. In addition to Russell, its first chair, the other members were fellow Britons Powell and Rotblat, Eugene Rabinowitch from the United States, and Dmitrii Skobel'tsyn from the Soviet Union. ${ }^{41}$

36. Joliot-Curie, Burhop, and Powell were all senior figures within the WFSW.

37. Rotblat, Pugwash, p. 80. The countries represented at the meeting in July 1957 were Australia, Austria, Canada, China, France, Japan, Poland, Great Britain, the United States, and the USSR.

38. Joseph Rotblat, "History of the Pugwash Movement," n.d. (ca. 1961), in RTBT, 5/1/1/4, CAC.

39. See the references in RTBT, 5/2/1/10 (3), p. 3, CAC.

40. Memorandum for first meeting of the Pugwash Continuing Committee, 15 December 1957, in RTBT 5/2/1/1-15, CAC.

41. In 1958, the Continuing Committee was expanded to a membership of nine-three each from Britain, the United States, and the USSR. In 1962 the composition was changed to two members each for Britain, the United States, and the Soviet Union, with one member each from Eastern and Western Europe and from India or Japan. 
The committee met for the first time in December 1957 amid the tense political situation created by the recent breakdown of UN disarmament talks in London and decided to convene a second conference in April 1958 in LacBeauport, Canada. The Continuing Committee met two or three times a year, for the most part in London-initially out of consideration for the aging and increasingly frail Russell; later because Rotblat, who was appointed secretary general in 1959 after a stint as secretary from 1957, was based there. ${ }^{42}$ Rotblat's post, which he held until 1973, accorded him the only permanent seat on the Continuing Committee. Membership was otherwise set on a rotating basis, with the number of members increased to nine in 1958. The committee exercised a controlling influence over the development of Pugwash, directing and coordinating its activities, formulating practices and protocols, deciding on the venue for, topics of, and participation in the annual conferences, and devising and revising overall strategy. ${ }^{43}$ The Continuing Committee gave priority to dissemination of the work and views of Pugwash, including conference proceedings and, from 1959 on, a quarterly newsletter, both of which were distributed free of charge to all Pugwashites, heads of state, and various interested individuals and institutions (roughly 850 copies).

The future viability of Pugwash was contingent on financial support. Initially, this had come from Eaton, who had built up the third-largest steel company in the United States and had agreed to fund the first, second, and fifth conferences. As Pugwash moved into its third year, the Continuing Committee severed ties with Eaton, whose anti-war activities came to be seen, especially by the U.S. public, as pro-Soviet. The break with Eaton reflected concerns within Pugwash that continued association with him was undermining its political neutrality. The third and fourth conferences, held in Kitzbühel/Vienna (1958) and Baden (1959) in Austria, were largely funded by the private Austrian Theodor Körner Foundation. Examining this early Austrian support for Pugwash, Elizabeth Röhrlich shows that it reflected the Austrian government's wider strategy to position the country as a "hub" within the emerging international nuclear order. Throughout this early period, Pugwash got by on what Rotblat called a "shoestring" budget, reducing costs wherever possible. From the outset, for example, travel costs were minimized by staging conferences just before or after, and in the same locations as, major scientific

42. On Rotblat, see Martin Underwood, "Joseph Rotblat and the Moral Responsibilities of the Scientist," Science and Engineering Ethics, Vol. 15, No. 2 (June 2009), pp. 129-134; and Brown, Keeper.

43. The powerful influence of the Continuing Committee is apparent in the records of its meetings and work, which are held in the Rotblat Collection in RTBT, CAC. 
conferences. ${ }^{44}$ Private donations continued to be important, especially in supporting the expanding portfolio of Pugwash activities, although those donating money typically preferred to remain anonymous. In the 1960s, Pugwash conferences were financed by the national science academy of the country in which the meeting was to be held. Although this afforded some stability and was arguably a marker of prestige, the arrangement had a political dimension. As the articles by Gordon Barrett, Doubravka Olšaková, and Carola Sachse discuss in the cases of China, Czechoslovakia, and West Germany, the national scientific institutions also played a major role as liaisons between scientists and the national government in matters pertaining to Pugwash.

At the third conference in Kitzbühel/Vienna in September 1958, steps were taken to give the fledgling movement stronger organizational form and a stronger sense of overall strategy. In a pragmatic move, the Continuing Committee called for the creation of national groups as a means to gain a foothold in various countries. By 1962, ten such groups had been formed, with a further twelve groups created by 1967. In January 1967, Pugwash held what it referred to as its first Southeast Asian regional conference in Melbourne, Australia. ${ }^{45}$ In building this novel infrastructure, Pugwash was positioning itself at the intersection between the national and the international, a reflection of its concern to transcend the interests of the nation-state. This also offered one means of incorporating connectivity and cohesion into the framework of an initiative otherwise organized around annual conferences that sought primarily to foster dialogue among scientists who came together because of their scientific expertise and a shared commitment to the founding aims of Pugwash. The national groups served as nodes in a steadily expanding network and were the means by which Pugwash established a presence around the world. Each national group operated in its own way, monitoring nuclear-related developments and reporting on these to the Continuing Committee, where information was assessed and adapted for Pugwash activities and strategy. The possibility of transnational flows and exchanges was therefore embedded in and realized through the novel network-like structure of Pugwash in an arrangement comprising individuals and national and regional groups.

The third Pugwash meeting in Austria in 1958 was also highly significant for the publication of a statement that expanded on the aims of Pugwash and was important in defining its spheres of action and consolidating its identity.

44. Rotblat, Pugwash, p. 65.

45. Ibid., pp. 225-231. The countries represented were Australia, Ceylon (Sri Lanka), India, Indonesia, Japan, Malaysia, New Zealand, Pakistan, and Singapore. Also in attendance were observers from the UN and the Australian Department of External Affairs. 
Eventually known as the Vienna Declaration, this document enumerated basic principles of the Pugwash Movement and contained seven sections, each of which outlined an area of Pugwash activity: (1) the necessity to end wars, (2) requirements for ending the arms race, (3) what world war would mean, (4) the hazards of bomb tests, (5) science and international cooperation, (6) technology in the service of peace, and (7) the responsibilities of scientists. The fifth section, on science and international cooperation, asserted the existence of a distinctive bond between scientists and their special position in society and crystallized how both were pivotal to Pugwash and the role they envisaged for it in the global struggle against nuclear weapons. As this section emphasized, scientists involved in Pugwash believed that understanding among scientists with different national allegiances "is an excellent instrument for bridging the gap between nations and for uniting them around common aims." ${ }^{46}$

The annual conferences brought Pugwashites together and provided a forum for discussing issues related to nuclear weapons and for networking. The venue changed each year, conferences typically lasted three to five days, and the format varied. The program always included discussions of papers given by delegates and sessions given to debate on topical issues, which were often heated and sometimes fractious. The number of delegates at the conferences grew steadily from 22 (Pugwash, 1957) to 175 (London, 1962). By the tenth conference in 1962, 25 countries were represented, and in 1977, 223 participants from 47 countries celebrated the twentieth anniversary of the Pugwash conferences in Munich. ${ }^{47}$ Attendance was on an invitation-only basis, with participants selected by the Continuing Committee. Discussions were conducted in private but with a record of each meeting published in the form of a statement including key findings and broad recommendations and made available to both politicians and the wider public around the world. The portfolio of Pugwash activities was also carefully expanded. For example, in a move to foster closer analysis of key issues, smaller meetings and symposia were established. At Karlovy Vary in 1964, study groups were introduced to facilitate in-depth analysis of (1) European security, (2) biological weapons,

46. The Vienna Declaration has been reproduced frequently. For example, see Rotblat, Pugwash, pp. 90-97.

47. Report of Secretary General, London, 1962, p. 4, in RTBT 5/2/1/10 (3), CAC; and Klaus Gottstein, "Erinnerungen an Pugwash und an die Rolle der VDW als deutsche Pugwash-Gruppe," in Götz Neuneck and Michael Schaaf, eds., Zur Geschichte der Pugwash-Bewegung in Deutschland (Berlin: Max-Planck-Institut für Wissenschaftsgeschichte, 2007), pp. 39-51. 
(3) East-West integration, and (4) the United Nations Educational, Scientific and Cultural Organization. ${ }^{48}$

The changing nature of the discussions within Pugwash transformed perceptions of the organization within governmental circles, even if some suspicions remained. ${ }^{49}$ Over the course of the 1960s and 1970s, views of it as politically unreliable gradually gave way to a recognition that, in affording a rare channel of East-West communication, it was emerging as a valuable site of second-track diplomacy in nuclear matters. Through its meetings, its networks, and its widening range of research activities-for example, various national groups routinely engaged in studies about the implications of nuclear weapons and the question of building a sustainable peace-Pugwash was increasingly seen as useful on both sides of the East-West divide and within the Non-Aligned Movement. By 1967, Rotblat could note with some satisfaction that Pugwash served as "an unofficial channel of communication through which ideas could be ventilated before they were taken up officially." ${ }^{50}$ His description suggests that one of the fundamental contributions of Pugwash was in creating the possibility for and conditions conducive to dialogue across political and ideological divides, thus underpinning the organization's role as a place in which back channels could be forged and sustained.

Pugwash defies easy characterization, however. Given the attendance of official delegations of scientists from the Communist world, Lawrence Scheinmann in 1971 expressed doubt that Pugwash "consistently qualifies as a nongovernmental organization." ${ }^{51}$ Some questions might also be asked about the relationships between those attending Pugwash meetings and government agencies in the liberal democratic West. John Krige, for example, has claimed that intelligence gathering played a role in the scientific exchanges connected with President Dwight D. Eisenhower's Atoms for Peace initiative. ${ }^{52}$ This point resonates with Ron Doel's concept of "science in black." Analyzing U.S. policy during the Cold War, Doel traces the history of the "large, unexplored continent of interconnections, maintained in secrecy, between scientists and public officials mutually interested in adopting science to serve (US) interests

48. Rotblat, Pugwash, p. 65.

49. For example, Solly Zuckerman, "Report to Ministry of Defence," 26 September 1961, in RTBT, 5/1/3/7, CAC.

50. C. 1967 , in RTBT, 5/3/1/19, CAC.

51. Lawrence Scheinmann, "Security and a Transnational System: The Case of Nuclear Energy," International Organization, Vol. 25, No. 3 (Summer 1971), p. 647.

52. John Krige, "Atoms for Peace, Scientific Internationalism, and Scientific Intelligence," Osiris, Vol. 21, No. 1 (January 2006), pp. 161-181. 
and the national security state." ${ }^{53}$ Pugwashites were bound together by the loose ties that can form between those who share professional training and a value system. In that respect, the Pugwash conferences were more an INGO than a looser network that reflected the common values and assumptions of a transnational "epistemic community" in the way Peter Haas has defined itthat is, one in which scientists formulated "alternative actions" that were, in turn, "shaped by belief systems, operational codes, and cognitive maps." ${ }^{54}$ Yet, until 1991, Pugwash resisted registration with the UN as a non-governmental organization. Instead, scientists who attended meetings were encouraged to refer to themselves as "Pugwashites" and during the first decade referred to Pugwash as a "movement." But, as John Krige has pointed out, it is unclear whether the social-scientific criteria for "movement" (especially in its clear and direct links to protest activity) really apply to Pugwash. ${ }^{55}$ Definitions aside, Pugwash was clearly the nodal point in a network that reached into other contexts, including transatlantic strategic studies, defense, and the peace research community. Its importance as a conduit for second-track diplomacy during and after the Cold War is only now beginning to come to light. ${ }^{56}$

\section{Pugwash in the Context of Cold War International Relations}

If the Russell-Einstein Manifesto and Pugwash were most immediately a response to the material reality of the hydrogen bomb and its new dangers, they can be fully understood only when situated in the wider context of the global Cold War in the mid-1950s. In thinking about the political conditions that enabled scientists from East and West to mobilize in this way at this time, we would highlight four geopolitical developments. The most important of these was the changing political situation in the Soviet Union after Iosif Stalin's

53. Ronald Doel, "Scientists as Policy Makers, Advisors and Intelligence Agents: Linking Contemporary Diplomatic History with the History of Contemporary Science," in Thomas Soderqvist, ed., Historiography of Contemporary Science and Technology (Amsterdam: Harwood Academic, 1997), p. 216.

54. Peter M. Haas, "Introduction: Epistemic Communities and International Policy Coordination," International Organization, Vol. 46, No. 1 (Winter 1992), p. 28; and Mia’a K. Davis Cross, "Rethinking Epistemic Communities Twenty Years Later," Review of International Studies, Vol. 39, No. 1 (January 2013), pp. 137-160.

55. In closing comments at the workshop "Writing Pugwash Histories," held at the University of Vienna, 10-12 May 2012, John Krige emphasized the pitfalls of characterizing Pugwash as a "movement," arguing that it has little in common with social movements in the classic or "new" mold and, as such, might better be described as an NGO.

56. See the studies by Evangelista, Unarmed Forces; Bernd W. Kubbig, "Communicators in the Cold War"; Kubbig, Wissen als Machtfaktor; and Hauswedell, Friedenswissenschaften. 
death, when a "thaw" emerged in Nikita Khrushchev's early years that also allowed for a somewhat more cooperative approach in international relations. This climate of détente was apparent in official diplomacy, including the beginning of disarmament negotiations in 1954 and the Geneva summit of July 1955, the first meeting of Soviet and U.S. leaders since Potsdam in 1945. ${ }^{57}$ The new climate was also evidenced by visits of world leaders to Moscow, including that in 1955 by Indian Prime Minister Jawaharlal Nehru, who was emerging as a leading figure in the NonAligned Movement and was spearheading calls for an end to nuclear weapons testing and the arms race..$^{58}$ According to Evangelista, the thaw provided the "political preconditions for a transnational dialogue of scientists." ${ }^{59}$ In the shadow cast by the hydrogen bomb and during the brief window of diplomatic opportunity created by the political restructuring of a decolonizing world, the superpowers conceded the possibility and value of international gatherings of scientists involved in nuclear research.

Second, we would highlight the Atoms for Peace initiative as important to the origins of Pugwash. Launched by President Eisenhower in a speech at the UN in December 1953, the initiative linked nuclear energy to the establishment of peace and prosperity. Ulrike Wunderle has interpreted Pugwash as a direct byproduct of scientists' dashed hopes that Atoms for Peace might lead to détente.$^{60}$ Eisenhower had sought, in the context of the U.S. development of hydrogen bombs and a move toward a strategy of massive retaliation with nuclear weapons, to wrest "peace" as a propaganda tool away from the Soviet Union. ${ }^{61}$ However, a precedent for international scientific conferences was set

57. On disarmament, see Philip Noel-Baker, The Arms Race: A Programme for World Disarmament (London: Atlantic Books, 1958); and Matthew Evangelista, "Cooperation Theory and Disarmament Negotiations," World Politics, Vol. 42, No. 4 (July 1990), pp. 502-528. For a contrasting view on the "moment of hope," see Spyros Blavoukos and Dimitris Bourantonis, "Calling the Bluff of the Western Powers in the UN Disarmament Negotiations, 1954-1955," Cold War History, Vol. 14, No. 3 (July 2014), pp. 359-376.

58. Vijay Prashad, The Darker Nations: A People's History of the Third World (New York: New Press, 2008). On the general relevance from the perspective of US foreign policy, see Robert B. Rakove, Kennedy, Johnson, and the Nonaligned World (Cambridge, UK: Cambridge University Press, 2013).

59. Matthew Evangelista, "Transnational Actors," p. 403; Matthew Evangelista, "The Paradox of State Strength: Transnational Relations, Domestic Structures, and Security Policy in Russia and the Soviet Union," International Organization, Vol. 49, No. 1 (Winter 1995), pp. 1-38. Also, see Iriye, Global Community.

60. This is the argument made by Ulrike Wunderle, "Atome für Krieg und Frieden: Kernphysiker in Großbritannien und den USA im Kalten Krieg," in Neuneck and Schaaf, eds., Pugwash, pp. 17-29, and in her Experten im Kalten Krieg: Kriegserfahrungen und Friedenskonzeptionen US-amerikanischer Kernphysiker 1920-1963 (Paderborn: Schöningh, 2015).

61. Krige, "Atoms for Peace," p. 162; Kenneth Osgood, Total Cold War: Eisenhower's Secret Propaganda Battle at Home and Abroad (Lawrence, KS: University Press of Kansas, 2006), ch. 5; and Ira Chernus, Apocalypse Management: Eisenhower and the Discourse of National Insecurity (Stanford, CA: Stanford University Press, 2008). 
by the first Atoms for Peace conference, which brought together scientists from East and West in Geneva in 1955.

Third, the political leaders of the nuclear states had been made fully aware of the shocking implications of the hydrogen bomb by secret studies into the effects of thermonuclear war, which highlighted how catastrophic any major war was likely to be. ${ }^{62}$ In the shadow of the bomb, as David Holloway has put it, the political leaders of the nuclear states had come to understand "that nuclear war was unacceptable in some profound, if ill-defined, way." ${ }^{63}$

Finally, we would highlight the importance of the nuclear weapons program of the British government during this period. Winston Churchill's decision to develop the hydrogen bomb coincided with the debate over the Fukuryu Maru incident, and the project got under way against the backdrop of the mounting controversy about fallout and its potential dangers. These circumstances are important in understanding the leading role played by British scientists — most prominently, Russell, Rotblat, Powell, and Burhop-in both the manifesto and the inception of Pugwash. As discussed in Kraft's article in this issue of the journal, their involvement was grounded in a fundamental opposition to the pro-nuclear weapons policy of the British government, their frustration with the secrecy surrounding British nuclear programs, and British officials' denial that fallout posed a danger to health. The scientists were acutely aware that Britain, as the third nuclear power, would likely set a precedent for other smaller countries harboring nuclear and thermonuclear ambitions. ${ }^{64}$

\section{A Framework of Enquiry}

Our aim here is not to tell a straightforward story that adds "anti-warriors" to the tale of militarized science during the Cold War. ${ }^{65}$ Instead, we seek to explore in finer detail how, why, and to what effect scientists were able, under

62. Jeff Hughes, "The Strath Report: Britain Confronts the H-Bomb, 1954-1955," History and Technology, Vol. 19, No. 3 (September 2003), pp. 257-275.

63. Cited in David Holloway, "Nuclear Weapons and the Escalation of the Cold War, 1945-1962," in Leffler and Westad, eds., The Cambridge History, p. 383. See also the path-breaking contribution by Tannenwald, Nuclear Taboo.

64. Colette Barbier, "The French Decision to Develop a Military Nuclear Programme in the 1950s," Diplomacy and Statecraft, Vol. 4, No. 1 (March 1993), pp. 103-113; and Jan Melissen, "Nuclearizing NATO, 1957-1959: The 'Anglo-Saxons,' Nuclear Sharing and the Fourth Country Problem," Review of International Studies, Vol. 20, No. 3 (July 1994), pp. 253-275.

65. Melvin Small, Antiwarriors: The Vietnam War and the Battle for American Hearts and Minds (Wilmington, DE: Scholarly Resources, 2002). 
the auspices of Pugwash, to fashion and hone roles as political and transnational actors. In so doing, we hope to illuminate more fully the realm of science and scientists during the Cold War. One of the central characteristics of the Cold War was the fact that it involved a nuclear arms race in the context of an ideological confrontation. Nuclear scientists were concerned with a key technology of military power and seemed to possess knowledge of the arcana imperii of Cold War power. ${ }^{66}$ This also marked out scientists on both sides of the Iron Curtain for particular observation as potential agents of subversion. ${ }^{67}$ Scientists' high-profile status as symbolic markers for national self-esteem and their activities in international conferences and research collaborations, together with what for some were transnational biographies linked to exile in the 1930 s, made them especially plausible targets for such allegations. ${ }^{68}$ Nonetheless, their research also symbolized the transnational, even global allure of nuclear energy for the projects of social and economic modernization in what came to be called the "nuclear age": Until the 1970s, nuclear energy was seen as a principal marker of modernity and national standing. ${ }^{69}$

The contributions assembled here highlight how the individual scientists engaged in Pugwash negotiated these demands, both in the West and in the Communist dictatorships in the East. ${ }^{70}$ In so doing, they reveal the contradictory and contingent politics at work within Pugwash: The national resonances

66. For a general overview of the historiography, see Holger Nehring, "What Was the Cold War?" The English Historical Review, Vol. 127, No. 572 (August 2012), pp. 920-949.

67. Wang, American Science; and Ellen Schrecker, Many Are the Crimes: McCarthyism in America (Princeton, NJ: Princeton University Press, 1999).

68. David Kaiser, "The Atomic Secret in Red Hands? American Suspicions of Theoretical Physicists during the Early Cold War," Representations, Vol. 90, No. 1 (Spring 2005), pp. 30-31; Laucht, Elemental Germans, chs. 4-5; Christoph Laucht, "Los Alamos in a Way Was a City of Foreigners': German-Speaking Émigré Scientists and the Making of the Atom Bomb at Los Alamos, New Mexico, 1943-1946," New Mexico Historical Review, Vol. 86, No. 2 (Spring 2011), pp. 223-250; and the contributions by Gordon Barrett on China and Doubravka Olšáková on Czechoslovakia in this issue of the journal.

69. Holger Nehring, "Cold War, Apocalypse and Peaceful Atoms: Interpretations of Nuclear Energy in the British and West German Anti-Nuclear Weapons Movements, 1955-1964," Historical Social Research, Vol. 29, No. 3 (January 2004), pp. 150-170; Jacob Darwin Hamblin, "The Nuclearization of Iran in the Seventies," Diplomatic History, Vol. 38, No. 5 (November 2014), pp. 1114-1135; Dick van Lente, ed., The Nuclear Age in Popular Media: A Transnational History, 1945-1965 (New York: Palgrave, 2012); and Itty Abraham, ed., South Asian Cultures of the Bomb: Atomic Publics and the State in India and Pakistan (Bloomington, IN: Indiana University Press, 2009). On the general context, see Nils Gilman, Mandarins of the Future: Modernization Theory in Cold War America (Baltimore: Johns Hopkins University Press, 2003); and Michael E. Latham, Modernization as Ideology: American Social Science and "Nation Building" in the Kennedy Era (Chapel Hill: University of North Carolina Press, 2000).

70. See Agar, Science, p. 354; Daniel J. Kevles, The Physicists: The History of a Scientific Community (Cambridge, MA: Harvard University Press, 1995); Carola Sachse and Mark Walker, "Introduction: A Comparative Perspective," in the special issue they edited, "Politics and Science in Wartime. 
of Communism and anti-Communism differed both between countries and over time. ${ }^{71}$

At stake, then, in this theme issue are the possibilities for and the role of internationalism during an era that David Reynolds has described as "One World Divisible," divided between East and West and North and South. ${ }^{72}$ Scientists have, because of the universality attached to their claims and the common language they use, often been seen as actors who could bridge such divides. ${ }^{73}$ Science and scientists have therefore often been regarded in political circles as a key means of deploying "soft power"; namely, by linking scientific internationalism to specific values and interests. ${ }^{74}$ However, such views of the role of science were, as this collection of articles shows, deeply embedded in specifically national interpretations of the purpose and mission of science. ${ }^{75}$

Comparative Perspectives on the Kaiser Wilhelm Institutes,” Osiris, Vol. 20 (2005), pp. 1-20; and Mitchell G. Ash, "Wissenschaft und Politik als Ressourcen füreinander," in Rüdiger vom Bruch, ed., Wissenschaften und Wissenschaftspolitik: Bestandsaufnahmen zu Formationen, Brüchen und Kontinuitäten im Deutschland des 20. Jahrhunderts (Stuttgart: Steiner, 2002), pp. 32-51.

71. For an exploration of the misunderstandings that resulted, see John Krige, Hegemony, ch. 5. On the general context, see Thomas Mergel, "The Unknown and the Familiar Enemy: The Semantics of Anti-Communism in the USA and Germany, 1945-1975," in Willibald Steinmetz, ed., Political Languages in the Age of Extremes (Oxford, UK: Oxford University Press, 2011), pp. 245-274.

72. David Reynolds, One World Divisible: A Global History since 1945 (New York: W. W. Norton, 2000).

73. On the development and status of such universal languages of science see Michael Gordin, Scientific Babel: The Language of Science from the Fall of Latin to the Rise of English (New York: Profile Books, 2015).

74. See Ronald E. Doel, "Scientists as Policymakers, Advisors and Intelligence Agents: Linking Contemporary Diplomatic History with the History of Contemporary Science," in Thomas Söderqvist, ed., The Historiography of Contemporary Science and Technology (Amsterdam: Harwood, 1997), pp. 215-244; Jacob Darwin Hamblin, "Visions of International Scientific Cooperation: The Case of Oceanic Science, 1920-1955,” Minerva, Vol. 38, No. 4 (December 2000), pp. 393-423; Joseph Manzione, "Amusing and Amazing and Practical and Military': The Legacy in Scientific Internationalism in American Foreign Policy, 1945-1963," Diplomatic History, Vol. 24, No. 1 (Winter 2000), pp. 21-56; and Clark A. Miller, "An Effective Instrument of Peace': Scientific Cooperation as an Instrument of U.S. Foreign Policy, 1938-1950,” Osiris, Vol. 21, No. 1 (January 2006), pp. 133-160. On "soft power," see the key text by Joseph S. Nye, Jr., Soft Power: The Means of Success in World Politics (New York: Public Affairs, 2004). For a case study in a different field, see Maxine Berg, "East-West Dialogues: Economic Historians, the Cold War, and Détente,” Journal of Modern History, Vol. 87, No. 1 (March 2015), pp. 36-71.

75. Krige, Hegemony, pp. 148-149. For background, see the chapter "The Defense of Democracy and Robert K. Merton's Formulation of the Scientific Ethos," in David Hollinger, Science, Jews, and Secular Culture: Studies in Mid-Century American Intellectual History (Princeton, NJ: Princeton University Press, 1996), pp. 80-96; and Gabriele Metzler, Internationale Wissenschaft und nationale Kultur: Deutsche Physiker in der internationalen Community (Göttingen: Vandenhoeck \& Ruprecht, 2000). For predecessors, see the chapter on "Internationalism in Science as a Casualty of World War I," in Elisabeth Crawford, Nationalism and Internationalism in Science, 1880-1939: Four Studies of the Nobel Population (New York: Cambridge University Press, 1992), pp. 49-78. On the general interplay between nationalism and internationalism, see Holger Nehring, "National Internationalists: British 
The articles collected here point to the need for critical reflection and careful consideration of the ways scientists and governments interpreted the role of science in the context of democracy and dictatorship. They also indicate how an assessment of scientists' involvement in military developments during the Cold War can be fully grasped only when linked to the question of mobilization of science and scientists for war from the 1930s into the 1940s, which in Japan and Germany was also a question of resistance against and collaboration with tyranny. ${ }^{76}$ These different experiences of the mobilization of science for war also framed older and more established notions about the nature of scientists' political involvement in Pugwash. West German scientists emphasized the alleged political neutrality (indeed, the unpolitical nature) of science and scientists in Germany, not least to bypass the question of participation in the Nazi bomb project. ${ }^{77}$ By contrast, scientists in Great Britain and in the Soviet bloc were more explicit in their notions of the political and social importance of science in society. ${ }^{78}$

The ideal that scientists - by means of their shared language of sciencewere especially able to put their political differences and ideological commitments aside in order to bridge differences between political systems and nations — and thus to ease Cold War tensions-proved difficult in practice.

and West German Protests against Nuclear Weapons, the Politics of Transnational Communications and the Social History of the Cold War, 1957-1964," Contemporary European History, Vol. 14, No. 4 (November 2005), pp. 559-582. On Cold War rationality, see Paul Erickson et al., How Reason Almost Lost Its Mind: The Strange Career of Cold War Rationality (Chicago: Chicago University Press, 2013).

76. Richard H. Beyler and Morris F. Low, "Science Policy in Post-1945 West Germany and Japan: Between Ideology and Economics," in Mark Walker, ed., Science and Ideology: A Comparative Perspective (London: Routledge, 2003), pp. 197-203; Mitchell G. Ash, "Denazifying Scientists and Science," in Matthias Judt and Burghard Ciesla, eds., Technology Transfer out of Germany after 1945 (Amsterdam: Harwood Academic Publishers, 1996), pp. 61-79; and Mark Walker, "The Nazification and Denazification of Physics," in Judt and Ciesla, eds., Technology Transfer, pp. 49-59. The myth of German scientists' non-involvement in the Nazi bomb project was largely created by Robert Jungk, Brighter than a Thousand Suns: A Personal History of the Atomic Scientists (New York: Harcourt Brace, 1958). For a critique, see Mark Walker, Nazi Science: Myth, Truth and the German Atomic Bomb (New York: Plenum Press, 1995); and Mark Walker, "Legenden um die deutsche Atombombe," Vierteljahrshefte für Zeitgeschichte, Vol. 38, No. 1 (January 1990), pp. 45-74.

77. For example, see Cathryn Carson, "New Models for Science in Politics: Heisenberg in West Germany," Historical Studies in the Physical and Biological Sciences, Vol. 30, No. 1 (January 1999), p. 122; Arne Schirrmacher, "Physik und Politik in der frühen Bundesrepublik Deutschland: Max Born, Werner Heisenberg und Pascual Jordan als politische Grenzgänger," Beiträge zur Wissenschaftsgeschichte, Vol. 30, No. 1 (March 2007), pp. 13-31; and Walker and Sachse, eds., "Politics and Science in Wartime."

78. The same was true of the United States and France. See Gary Werskey, The Visible College: The Collective Biography of British Scientific Socialists of the 1930s (New York: Holt, 1978); Peter J. Kuznick, Beyond the Laboratory: Scientists as Political Activists in 1930s America (Chicago: University of Chicago Press, 1987); Dominique Pestre, "Scientists in Time of War: World War II, the Cold War, and Science in the United States and France," French Politics, Culture \& Society, Vol. 24, No. 1 (April 2006), pp. 27-39; and Laucht, Elemental Germans. 
The notion that Pugwashites were completely independent and detached from any sense of national allegiance, representing "nobody but ourselves," as Rotblat claimed, was not always borne out in discussion around the Pugwash table. ${ }^{79}$ The articles by Barrett on China, Kurosaki on Japan, and, in a different way, Sachse on West Germany show that, for many scientists, Rotblat's assessment did not reflect the reality of participation in Pugwash. Moments of political crisis in the early Cold War (e.g., the U-2 spy plane incident or the breakdown of the moratorium on atmospheric weapons testing in May and September 1960) exposed the problem of national allegiance and the fragility of the ideal of acting independently that was integral to the self-conception and presentation of Pugwash.

Moreover, the participation of countries in Pugwash was repeatedly shown to be contingent on the shifting sensibilities of individual governments amid the evolving contours of the Cold War. In particular, the articles by Barrett and Olšáková demonstrate that the patterns of participation by China and Czechoslovakia in the 1960s were shaped by their fraught and deteriorating relationships with the Soviet Union. In the case of China, participation was also influenced by the country's own nuclear weapons program. Barrett and Olšáková highlight how, within these national settings, Pugwashites were carefully selected and vetted for political reliability, given specific instructions and goals, and routinely briefed and debriefed by government officials before and after meetings. By contrast, as Kraft's article shows for the British case, Russell, Rotblat, and Powell, living and working in a political context in which dissent was possible, were political outsiders, regarded with suspicion by government and the nuclear establishment. ${ }^{80}$

\section{Conclusions and Avenues for Future Research}

This collection of articles seeks to contribute a new understanding of the material and political conditions that made Pugwash conceivable, possible, and sustainable; of the organization's development within each of the featured countries; and of the very different experiences of Pugwashites vis-à-vis their governments and the Cold War state. The articles also cast new light on the dynamics of the transnational encounter around the Pugwash table and enhance our understanding of how Pugwash was able to establish itself

79. RTBT, 5/2/1/10 (3), p. 3, in CAC.

80. Maguire, "Dissent." 
as a transnational actor and forge a unique role as interlocutor between science and politics during the early Cold War. Analysis of non-governmental international actors such as Pugwash helps to illuminate what Itty Abraham has called the "ambivalence of nuclear histories," namely, their potential for stressing the "fluidity of international affairs" against the seeming stability of the Cold War as a "long peace." 81

In particular, the articles presented here complicate our thinking about the impact of Pugwash on national nuclear weapons policy, the movement's role as a transnational actor, and, especially, its contributions to nuclear diplomacy and its relevance and meaning for Cold War history. The articles show how perceptions of Pugwash differed markedly across national boundaries and ideological divides and that perceptions also changed over time as the movement came to be viewed in East and West as a resource for the deployment of "soft power." Following from this, the articles reveal how different governments saw Pugwash as a means to particular ends that served the national interest. At the same time, they confirm the importance of scientists as both political and transnational actors while raising many questions about the complex (and often shifting) relationships between senior scientists and their respective governments in the early Cold War. This theme issue thus casts new light on how putting scientific social responsibility into practice under the auspices of Pugwash was fundamentally contingent on the political culture of the nation-state and the opportunities and constraints this placed on scientists.

Barrett shows how the Chinese government viewed Pugwash as a vehicle for "People's Diplomacy" and a forum in which to enhance the country's international image and strengthen its peace credentials. To this end, Chinese Pugwashites (notably, Zhou Peiyuan), were carefully selected, vetted, and briefed. Barrett demonstrates how Chinese participation in Pugwash was powerfully shaped by the country's relationship with the Soviet Union and by its development of nuclear and thermonuclear weapons. As Olšáková shows, the Soviet Union likewise exercised profound influence over Czechoslovakia's participation in Pugwash, an influence mediated through the Soviet Academy of Sciences and the World Peace Council. In the case of Japan, Kurosaki emphasizes how the particular sensitivity in Japanese society and politics to nuclear weapons and to radiation grounded a fierce political and public opposition to the development of these weapons and also to the principle of deterrence. The acceptance of this principle as a basis for disarmament negotiations was widely

81. Abraham, "Ambivalence of Nuclear Histories," pp. 49, 56; and John Lewis Gaddis, "The Long Peace: Elements of Stability in the Postwar International System," International Security, Vol. 10, No. 4 (Spring 1986), pp. 99-142. 
criticized in Japan as having turned the "balance of terror" into an "axiom of peace." If this created domestic political difficulties for the Japanese government, which remained reliant on the United States for national security until 1968, it also made for tensions within Pugwash, which accepted the principle of deterrence as part of its approach to disarmament.

Sachse highlights the ambivalence of senior West German scientists, especially Carl Friedrich von Weiszäcker, and of the country's premier scientific institution, the Max Planck Society, toward Pugwash. She shows that this ambivalence reflected the experience of Nazi rule, the country's unique position within Cold War geopolitics, the virulent anti-Communism that characterized West German politics and society, the Federal Republic's relationship to the German Democratic Republic, and the interwoven projects of rehabilitating German science and nation building. Anti-Communism and nation-building were also present in the newly declared neutral Austria, where, as Röhrlich shows, the government was striving to establish itself. The Austrian capital, Vienna, became a major international hub in the emerging international nuclear order, notably as the site of the headquarters for the newly created IAEA. As Röhrlich emphasizes, strategic aims underpinned Austrian financial support for the third and fourth Pugwash conferences, which were held in the country.

Kraft's article highlights the key role British scientists played in the Russell-Einstein Manifesto and the inception of Pugwash and emphasizes the key place of the fallout issue in both initiatives. She examines the position of Russell and Rotblat as political outsiders who challenged the British government and the country's nuclear establishment both individually and, via the manifesto and Pugwash, by collective action. She also highlights the consequences of expressing dissenting views within a political system in which it was possible to do so openly.

In 2010, Hunter Heyck and David Kaiser posed the question, "Why revisit science and the Cold War?" In answer to this question, they argued that much remains to be done to understand the relationship between the local and the global, to "particularize the grand narrative," and to add complexity to and also challenge earlier narratives of the Cold War. ${ }^{82}$ Pugwash offers a rich site for such work, not least as a means to understand more fully the diverse and shifting role of scientists in the Cold War and their often uneasy relationship with the Cold War state.

82. Hunter Heyck and David Kaiser, "Focus: New Perspectives on Science and the Cold War: Introduction," Isis, Vol. 101, No. 2 (June 2010), p. 362. 
Emerging from the articles are several themes of interest to historians of the Cold War. Collectively, they reveal the variety of relationships scientists had with their governments. For example, some were perceived as politically reliable, others as unreliable; some as nuclear or political insiders, others as outsiders. They point also to how national patterns and frameworks of understanding international and global concerns helped to shape both perceptions of Pugwash and the ways the different national Pugwash groups functioned. Following from this, we propose that Pugwash affords entrée into exploring the importance of science and scientists in the processes of nationbuilding and the (re)establishment of national sovereignty during the Cold War. That scientists were differently placed in respect to their governments also profoundly influenced the opportunities for and limits on transnational activity.

The articles assembled here also suggest avenues for future research, such as the relations of Pugwash and Pugwashites to civil society and to social movements, the question of how Pugwash encountered and dealt with the problem of nuclear secrecy; the nature and implications of tensions within Pugwash (at the levels both of individual Pugwashites and the national groups) regarding its evolving work and identity; and the form and dynamics of the organization's distinctive kind of transnationalism—and how these changed over time. Another point of interest is the question of influence-which takes different forms and is difficult to measure. As these articles show, the expertise of scientists was both needed and valued by governments for weapons development and in disarmament negotiations. In one sense, Pugwash came to provide a resource on which governments could call, but doing so required the presence of their own scientists and scientific/policy advisors at its meetings. Its influence was both manifest in and contingent on this dynamic. The Pugwashites, for their part, were keen to influence- that is, put a brake on-the development of weapons and the arms race. To this end, their ideas and message had to reach the ear of government. The increasing participation of senior policymakers was thus crucial and by the early 1960s was changing the nature of the conversations at Pugwash meetings and the perception of Pugwash in these circles.

Although dominated by the superpower dynamics, Pugwash was not just about the United States and the Soviet Union. Each national group had its own concerns and agenda and sought opportunities at Pugwash to discuss, address, or advance them. Pugwash also provided a forum in which smaller countries could challenge the superpowers, as was the case in the later 1960s, when the United States was subjected to sharp criticism over the Vietnam 
War. ${ }^{83}$ Pugwash served from early on as a site for raising problems other than nuclear weapons and the arms race. By the mid-1960s, it also served as a forum for discussions about chemical and biological weapons and was turning its attention to such issues as global poverty and social inequality. Today, climate change is one of its key areas of action. We hope that this special issue and the questions raised by each of the articles will serve as a starting point for further sustained research into the global histories of Pugwash, as well as encourage greater consideration of non-governmental actors and transnational dynamics in science and technology during the Cold War.

\section{Acknowledgments}

Earlier versions of these articles were presented at the Writing Pugwash Histories workshop held at the University of Vienna in May 2012, available online at http://www.writing-pugwash-histories.org/project-description /workshops/. We thank the participants and, in particular, Matthew Evangelista and John Krige for their stimulating interventions, which are reflected in this introduction.

83. This was apparent, for example, at the 1965 and 1966 Pugwash Conferences held in Venice, Italy, and in Sopot, Poland, respectively. See Rotblat, Pugwash, pp. 52, 55. 